\title{
Pendapatan, Konsumsi dan Tingkat Kesejahteraan Pengrajin Batik Wanita KUB Pringmas di Desa Papringan Banyumas
}

\author{
Recha Pangestika ${ }^{1}$, Herman Sambodo ${ }^{2 *}$, Goro Binardjo ${ }^{3}$, Sodik Dwi Purnomo ${ }^{4}$ \\ ${ }^{1,2,3}$ Fakultas Ekonomi dan Bisnis, Universitas Jenderal Soedirman \\ ${ }^{4}$ Fakultas Ekonomika dan Bisnis, Universitas Wijayakusuma Purwokerto \\ *Correspondence email: herman.sambodo@unsoed.ac.id
}

\begin{abstract}
Abstrak_Tujuan penelitian ini untuk menganalisis kontribusi pendapatan pengrajin batik wanita terhadap pendapatan rumah tangga, pengaruh pendapatan pengrajin batik wanita KUB Pringmas terhadap pengeluaran konsumsi dan tingkat kesejahteraan pengrajin batik wanita KUB Pringmas. Populasi sebanyak 38 orang responden. Teknik pengambilan data melalui observasi disertai dengan wawancara dan kuesioner. Hasil penelitian menggunakan teknik analisis tabulasi silang dan regresi linear sederhana menunjukkan bahwa : (1) Sebanyak 94,74\% atau 36 orang pengrajin batik wanita berkontribusi rendah, rata-rata pendapatan pengrajin batik wanita kurang dari Rp 1.116 .667 setiap bulannya. (2) Pendapatan pengrajin batik wanita berpengaruh positif signifikan terhadap konsumsi rumah tangga. (3) Pengrajin batik wanita KUB Pringmas termasuk pada kategori belum sejahtera, namun kesejahteraan rumah tangga menggunakan indikator BKKBN sudah terpenuhi dan rata-rata berada pada kondisi Keluarga Sejahtera III Plus (KS III Plus). Implikasi dari temuan ini yaitu upaya pengrajin wanita meningkatkan kontribusi pendapatannya terhadap rumah tangga dengan menjadikan pekerjaan utama dan menambah jam kerja. Pengeluaran konsumsi makanan lebih diutamakan dibandingkan non-makanan. Upaya meningkatkan kesejahteraan dengan mengadakan pelatihan untuk meningkatkan keterampilan pengrajin batik wanita.
\end{abstract}

Kata Kunci: Kontribusi Pendapatan, Konsumsi Rumah Tangga, Tingkat Kesejahteraan

Abstract_The purpose of this study was to analyze the contribution of women's batik craftsmen income to household income, the influence of KUB Pringmas women's batik craftsman income on consumption expenditure and the welfare level of KUB Pringmas women's batik craftsmen. The population were 38 respondents. Data collection techniques through observation accompanied by interviews and questionnaires. The results of research using analytical techniques in the form of cross tabulation and simple linear regression showed that: (1) As many as $94.74 \%$ or 36 women batik craftmen contributed low, the average income of female

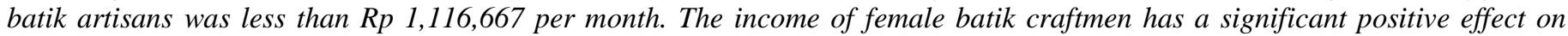
household consumption. (3) The batik craftsmen of KUB Pringmas are included in the category of not yet prosperous, but household welfare using the BKKBN indicator has been met and the average is in the condition Prosperous Family III Plus (KS III Plus). The implication of the above conclusion is that the efforts of women artisans to increase their income contribution to the household by making the main work and increasing working hours. Food consumption expenditure takes precedence over nonfood consumption. Efforts to improve welfare by holding training to improve the skills of women batik craftmen.

Keywords: Contribution of Income, Household Consumption, Welfare Level

\section{PENDAHULUAN}

Perkembangan digitalisasi 4.0 melalui teknologi canggih tercermin pada industri batik yang mampu bersaing di dunia internasional dengan keunggulan yang dimiliki. Berdasarkan data dari Kemenperin (Kementerian Perindustrian, 2019) tingkat ekspor industri batik pada tahun 2018 mencapai Rp 747 miliar atau sebesar US\$ 52,4 juta dan pada semester I 2019 ekspor batik mencapai Rp 253 miliar atau sebesar US\$ 17,99 juta.
Batik merupakan warisan nenek moyang yang tetap dilestarikan keberadaannya hingga sekarang, ragam corak dan warna batik menjadi ciri khas dan keunikan tersendiri. Semakin berkembangnya zaman penggunaan batik tetap dipertahankan dan melewati proses panjang hingga berujung pada pengakuan dunia pada 2 Oktober 2009 oleh United Nations Educational, Scientific and Cultural Organization (UNESCO) bahwa batik menjadi Masterpieces of the Oral and the Intangible Heritage of Humanity atau warisan kemanusiaan untuk budaya lisan dan non bendawi (Kompas, 2017).

Tabel 1. Penduduk Bekerja Menurut Lapangan Pekerjaan Utama dan Jenis Kelamin di Kabupaten Banyumas Tahun 2018 (Persentase)

\begin{tabular}{|c|c|c|c|}
\hline Lapangan Pekerjaan & Perempuan & Laki-Laki & Jumlah \\
\hline Pertanian,kehutanan dan perikanan & 15,19 & 18,64 & 17,28 \\
\hline Industri pengolahan & 22,24 & 16,61 & 18,83 \\
\hline Perdagangan, penyedia akomodasi \& makan minum & 42,60 & 28,77 & 34,23 \\
\hline Jasa & 15,64 & 11,05 & 12,86 \\
\hline Lainnya (penggalian,listrik,air dll) & 4,33 & 24,93 & 16,80 \\
\hline Jumlah & 100,00 & 100,00 & 100,00 \\
\hline
\end{tabular}

Sumber: Sakernas Agustus 2018 
Recha Pangestika, Herman Sambodo, Goro Binardjo dan Sodik Dwi purnomo, Pendapatan, Konsumsi dan Tingkat Kesejahteraan Pengrajin Batik Wanita KUB Pringmas di Desa Papringan Banyumas

Tabel 1 menunjukkan bahwa industri pengolahan menduduki peringkat kedua setelah perdagangan, penyedia akomodasi dan makan minum. Jumlah penduduk yang bekerja di industri pengolahan didominasi oleh penduduk wanita yaitu sebesar 22,24 persen, sedangkan penduduk laki-laki hanya sebesar 16,61 persen.

Tabel 2. Data Penduduk Berumur lebih dari 15 Tahun Menurut Lapangan Pekerjaan Kecamatan Banyumas Tahun 2018

\begin{tabular}{clrrrrc}
\hline Kode & Desa & Pertanian & Pertambangan \& Penggalian & Industri & Listrik,Gas \&Air & Konstruksi \\
\hline 1 & Binangun & 1.857 & 5 & 473 & 64 & 177 \\
2 & Pasinggangan & 2.966 & 35 & 1.912 & 89 & 965 \\
3 & Kedunggede & 822 & 9 & 345 & 21 & 216 \\
4 & Karangrau & 1.430 & 39 & 652 & 19 & 290 \\
5 & Kejawar & 937 & 19 & 322 & 36 & 319 \\
6 & Danaraja & 171 & 0 & 49 & 7 & 76 \\
7 & Kedunguter & 273 & 20 & 227 & 43 & 137 \\
8 & Sudagaran & 162 & 9 & 133 & 56 & 195 \\
9 & Pakunden & 344 & 22 & 416 & 30 & 243 \\
10 & Kalisube & 419 & 49 & 709 & 23 & 120 \\
11 & Dawuhan & 279 & 34 & 437 & 27 & 248 \\
12 & Papringan & 1.290 & 205 & 725 & 42 & 3.206 \\
\hline
\end{tabular}

Sumber: BPS Banyumas 2018

Tabel 2 menujukkan bahwa jumlah penduduk berumur lebih dari 15 tahun menurut lapangan pekerjaan kecamatan Banyumas tahun 2018, dapat dilihat dari jumlah industri di kecamatan Banyumas, posisi desa Papringan menduduki peringkat kedua yaitu sebesar 725 jiwa yang menekuni pekerjaan di bidang industri. Industri yang terdapat di Papringan berupa industri pengolahan batik, produksi makanan ringan, produksi batu bata dan produksi gula jawa (Dinas Tenaga Kerja, Koperasi \& UKM Kab. Banyumas Tahun 2018). Papringan sebagai salah satu sentra batik Banyumasan, di desa papringan ini membuat berbagai macam motif batik Banyumasan serta terdapat inovasi corak dan warna yang bervariasi sesuai dengan perkembangan zaman. Pembuatan batik di sentra batik papringan ini menggunakan teknik batik tulis, pengrajin menghubungkan antara satu titik ke titik lain agar menjadi sebuah gambar dengan menggunakan malam atau lilin dan proses pembatikan ini menghabiskan waktu lebih banyak tergantung pada kerumitan dari motif kain itu sendiri.

Tabel 3. Penduduk Berdasarkan Umur dan Jenis Kelamin Desa Papringan Tahun 2018

\begin{tabular}{|c|c|c|c|c|}
\hline Kelompok Umur & Laki-laki & Perempuan & Jumlah & Rasio Kelamin \\
\hline $0-4$ & 220 & 228 & 449 & 96.36 \\
\hline $5-9$ & 236 & 170 & 406 & 139.00 \\
\hline $10-14$ & 218 & 189 & 406 & 115.41 \\
\hline $15-19$ & 159 & 137 & 296 & 115.74 \\
\hline $20-24$ & 118 & 123 & 241 & 95.98 \\
\hline $25-29$ & 125 & 158 & 284 & 79.31 \\
\hline $30-34$ & 200 & 168 & 368 & 119.66 \\
\hline $35-39$ & 182 & 201 & 384 & 90.33 \\
\hline $40-44$ & 178 & 180 & 359 & 98.84 \\
\hline $45-49$ & 165 & 170 & 335 & 97.01 \\
\hline $50-54$ & 198 & 158 & 356 & 125.19 \\
\hline $55-59$ & 149 & 180 & 329 & 82.48 \\
\hline $60-64$ & 113 & 124 & 237 & 91.11 \\
\hline $65-69$ & 137 & 101 & 237 & 135.49 \\
\hline $70-74$ & 61 & 64 & 126 & 95.43 \\
\hline $75+$ & 109 & 107 & 216 & 102.67 \\
\hline Jumlah & 2.569 & 2.459 & 5.028 & 104.47 \\
\hline $0-14$ & 674 & 587 & 1.261 & 114.82 \\
\hline $15-64$ & 1.588 & 1.600 & 3.188 & 99.21 \\
\hline $65+$ & 307 & 272 & 579 & 113.12 \\
\hline Rasio Ketergantungan & 61.81 & 53.66 & 57.72 & \\
\hline
\end{tabular}

Sumber: BPS Registrasi Penduduk Kecamatan Banyumas 2018 
Tabel 3 di atas menunjukkan data pada tahun 2018 mengenai jumlah penduduk berdasarkan umur dan jenis kelamin Desa Papringan, dapat diketahui bahwa jumlah penduduk laki-laki di Desa Papringan tidak jauh berbeda dengan jumlah penduduk wanita atau perempuan yaitu penduduk laki-laki sebanyak 2.569 jiwa sedangkan penduduk perempuan sebanyak 2.459 jiwa. Berdasarkan usia kerja penduduk Desa Papringan berkisar antara 1564 tahun sebesar 3.188 jiwa dengan penduduk usia angkatan kerja perempuan sebesar 1.600 jiwa dan lakilaki sebesar 1.588 jiwa. Usia angkatan kerja lebih banyak perempuan dibandingkan dengan laki-laki.

Jumlah angkatan kerja mayoritas perempuan, beberapa perempuan khususnya ibu rumah tangga di Desa Papringan menjadi pengrajin batik. Pengrajin batik wanita di Papringan sudah ada sejak lama dan mendapatkan program bantuan pemerintah untuk pengembangan desa melalui Program Nasional Pemberdayaan Masyarakat- Program Penataan Lingkungan Permukiman Berbasis Komunitas (PNPMPLPBK). Pemerintah melihat kondisi bahwa Desa Papringan sudah mandiri sehingga pemerintah mengakhiri programnya pada tahun 2013. Setelah itu Bank Indonesia Kantor Perwakilan Purwokerto melihat potensi yang dimiliki Desa Papringan dalam kerajinan batik, selanjutnya Bank Indonesia Kantor Perwakilan Purwokerto membentuk Kelompok Usaha Bersama atau yang diberi nama KUB Pringmas dengan membagi kelompok-kelompok pengrajin batik dengan memberikan pembinaan dari proses awal hingga akhir dalam membatik. Kelompok Usaha Bersama Pringmas difasilitasi oleh Bank Indonesia Kantor Perwakilan Purwokerto berupa pendirian Showrom.

Desa Papringan menjadi sentra batik Banyumasan yang mana di dalamnya terdapat peran dari ibu rumah tangga sebagai seorang pengrajin batik yang mengisi waktu luangnya untuk menambah penghasilan terhadap keluarganya. Pengrajin batik sekaligus ibu rumah tangga di Desa Papringan, rata-rata hanya menghabiskan waktunya dalam memenuhi kebutuhan rumah tangganya saja. Hampir semua ibu rumah tangga di Desa Papringan menjadikan kegiatan membatik menjadi pekerjaan sampingan. Desakan ekonomi membuat ibu rumah tangga menjadi seorang pengrajin batik dikarenakan seorang ibu rumah tangga ingin membantu kondisi ekonomi rumah tangganya. Hal tersebut menjadi sumber pendapatan bagi seorang wanita dalam berkontribusi meningkatkan pendapatan rumah tangga dengan menjadi seorang pengrajin batik. Kontribusi yang diberikan relatif rendah karena pendapatan yang diperoleh seorang pengrajin masih dibawah UMK Kabupaten Banyumas. Menurut Gilarso (2003) teori Engel's menyatakan bahwa meningkatnya pendapatan rumah tangga membuat pengeluaran konsumsi non-makanan akan bertambah seiring dengan pendapatan yang diperoleh sedangkan konsumsi untuk makanan berkurang. Tingkat konsumsi pengrajin dipengaruhi oleh keseluruhan pendapatan yang diperolehnya, dimana adanya perubahan yang terjadi maka akan mempengaruhi tingkat kesejahteraan pengrajin batik wanita itu sendiri maupun rumah tangga pengrajin batik wanita tersebut.

Berdasarkan latar belakang tersebut, disusunlah beberapa pertanyaan penelitian sebagai berikut: Bagaimana kontribusi pendapatan pengrajin batik wanita KUB Pringmas terhadap pendapatan rumah tangga, pengeluaran konsumsi pengrajin batik wanita KUB Pringmas, dan tingkat kesejahteraan pengrajin batik wanita KUB Pringmas dan kesejahteraan rumah tangga di Desa Papringan?

\section{METODE}

Penelitian ini termasuk ke dalam metode penelitian deskriptif kuantitatif. Data diperoleh melalui data primer dengan melakukan survei langsung ke lokasi dengan menggunakan metode wawancara berdasarkan kuesioner dan observasi. Lokasi penelitian ini akan dilakukan di Desa Papringan, Kecamatan Banyumas, Kabupaten Banyumas. Waktu pelaksanaan penelitian ini untuk pengambilan data dilakukan pada Januari 2020. Populasi dan sampel penelitian ini yaitu sensus untuk semua pengrajin batik wanita KUB Pringmas di Desa Papringan. Sumber data yang diperoleh dalam penelitian ini berupa data primer dan data sekunder. Data primer diperoleh secara langsung dari obyek penelitian atau pihak pertama yaitu pengrajin batik wanita KUB Pringmas di Desa Papringan. Data sekunder diperoleh dari studi pustaka dan Badan Pusat Statistik (BPS) Kabupaten Banyumas. Teknik pengumpulan data dalam penelitian ini berupa observasi dan disertai dengan wawancara berdasarkan kuesioner. Wawancara yang dilakukan berupa wawancara terstruktur, dimana peneliti telah menyiapkan berbagai pertanyaan. Data yang diperoleh melalui data cross section. Teknik analisis data yang digunakan Untuk menganalisis besarnya menganalisis kontribusi pendapatan erdapat kriteria pengujian untuk menetapkan besar kecilnya kontribusi pendapatan pengrajin batik wanita KUB Pringmas, yaitu sebagai berikut:

a. Kontribusi pendapatan < 50\% maka pendapatan pengrajin batik wanita berkontribusi rendah.

b. Kontribusi pendapatan $=50 \%$ maka pendapatan pengrajin batik wanita berkontribusi sedang.

c. Kontribusi pendapatan $>50 \%$ maka pendapatan pengrajin batik wanita berkontribusi tinggi.

Untuk menganalisis pengaruh pendapatan pengrajin batik wanita terhadap pengeluaran konsumsi pengrajin batik wanita KUB Pringmas di Desa Papringan digunakan regresi linear sederhana dan rumus menurut Sukirno (2000 yaitu sebagai berikut):

\section{$\mathbf{C}=\mathbf{a}+\mathbf{b Y d}$}

Keterangan:

C : Konsumsi atau Consumption

a : Autonomous Consumption 
Recha Pangestika, Herman Sambodo, Goro Binardjo dan Sodik Dwi purnomo, Pendapatan, Konsumsi dan Tingkat Kesejahteraan Pengrajin Batik Wanita KUB Pringmas di Desa Papringan Banyumas

b : MPC/ Marginal Propensity to Consume

Yd : Disposible Income

Untuk menganalisis tingkat kesejahteraan pengrajin batik wanita KUB Pringmas di Desa Papringan digunakan Standar Kebutuhan Hidup Layak dengan mengacu pada Upah Minimum Kabupaten Banyumas. Selanjutnya untuk menganalisis kesejahteraan rumah tangga pengrajin batik wanita digunakan indikator BKKBN (Badan Kependudukan dan Keluarga Berencana Nasional), terdapat 21 (dua puluh satu) indikator keluarga sejahtera menurut BKKBN

\section{HASIL DAN PEMBAHASAN \\ Kontribusi Pendapatan Pengrajin Batik Wanita KUB Pringmas di Desa Papringan}

Tabel 4. Data Kontribusi Pendapatan Pengrajin Batik Wanita KUB Pringmas dan Pendapatan Total Rumah Tangga

\begin{tabular}{|c|c|c|c|c|c|c|c|c|}
\hline \multirow{3}{*}{$\begin{array}{l}\text { Kontribusi Pendapatan } \\
\text { Pengrajin Batik Wanita }\end{array}$} & \multicolumn{6}{|c|}{ Pendapatan Total Rumah tangga } & \multirow{2}{*}{\multicolumn{2}{|c|}{ Total }} \\
\hline & \multicolumn{2}{|c|}{ Rendah } & \multicolumn{2}{|c|}{ Sedang } & \multicolumn{2}{|c|}{ Tinggi } & & \\
\hline & $\mathrm{n}$ & $\%$ & $\mathrm{n}$ & $\%$ & $\mathrm{n}$ & $\%$ & $\mathrm{n}$ & $\%$ \\
\hline Rendah $<50 \%$ & 5 & 13,16 & 19 & 50 & 12 & 31,58 & 36 & 94,74 \\
\hline Sedang $=50 \%$ & 0 & 0,00 & 0 & 0,00 & 0 & 0,00 & 0 & 0,00 \\
\hline Tinggi $>50 \%$ & 1 & 2,63 & 0 & 0,00 & 1 & 2,63 & 2 & 5,26 \\
\hline Total & 6 & 15,79 & 19 & 50 & 13 & 34,21 & 38 & 100,00 \\
\hline
\end{tabular}

Sumber: Data Primer Diolah, 2020

Berdasarkan hasil penelitian dengan 38 responden sebagai sensus dari pengrajin batik wanita KUB Pringmas di Desa Papringan Kecamatan Banyumas Kabupaten Banyumas diperoleh keterangan bahwa terdapat kontribusi pendapatan pengrajin batik wanita KUB Pringmas terhadap pendapatan rumah tangganya. Hasil dari tabulasi silang menjelaskan bahwa rata-rata pengrajin batik wanita KUB Pringmas berkontribusi rendah ( $<50 \%$ ) terhadap pendapatan rumah tangganya yaitu sekitar $94,74 \%$ atau sebanyak 36 orang responden, sisanya sekitar 5,26\% atau sebanyak 2 orang responden memiliki kontribusi tinggi ( $>50 \%$ ), sedangkan tidak ada respon yang memiliki kontribusi sedang $(=50 \%)$ terhadap pendapatan rumah tangganya. Jumlah responden yang berkontribusi rendah lebih mendominasi dibandingan dengan responden dengan kontribusi tinggi. Berbeda halnya dengan temuan putra et al, (2020) yang menganalisis pendapatan usaha tani kopi dengan mengunkan pendekatan metode hayami yang menunjukkan bahwa sebagian besar pendatan petani kopi tergolong tinggi.

Pendapatan rendah dalam penelitian ini $<\mathrm{Rp}$ 1.116.667, pendapatan sedang berkisar antara $\mathrm{Rp}$ 1.116 .668 - Rp 2.233.335, sedangkan pendapatan tinggi $>\mathrm{Rp}$ 2.233.336. Rata-rata pengrajin batik wanita tersebut memperoleh pendapatan kurang dari $\mathrm{Rp}$ 1.116.667 setiap bulannya. Masing-masing pengrajin batik wanita memperoleh pendapatan yang berbeda antara pengrajin batik wanita yang satu dengan pengrajin batik wanita lainnya. Perbedaan pendapatan dalam KUB Pringmas ini berdasar pada lama kerja seorang pengrajin batik wanita menekuni pekerjaan menjadi pembatik ini, seorang pengrajin batik yang telah lama ada dalam dunia membatik sudah memahami teknik yang baik dan benar dalam menorehkan lilin di atas lembaran kain sehingga, dengan mudahnya menyelesaikan tugasnya dalam waktu yang lebih cepat karena pengrajin tersebut lebih cekatan dalam membatik.

Pengrajin batik wanita KUB Pringmas merupakan ibu rumah tangga yang bertugas menjalankan atau mengelola rumah dan bertanggung jawab terhadap rumah tangganya. Disamping kewajiban yang harus dijalankannya tersebut, ibu rumah tangga menggunakan waktu luangnya disela-sela pekerjaan rumah tangganya untuk bekerja menjadi pengrajin batik wanita di KUB Pringmas. Jumlah rata-rata pendapatan lain-lain yang diperoleh anggota keluarga selain dari pengrajin batik wanita yaitu sebesar Rp2.976.316. Besarnya rata-rata pendapatan lain-lain tanpa adanya tambahan dari pendapatan pengrajin batik wanita tergolong jumlah yang cukup tinggi melebihi jumlah rata-rata UMK di Kabupaten Banyumas. Upah Minimum Kabupaten/Kota pada 35 kabupaten/kota di Provinsi Jawa Tengah Tahun 2020 menunjukkan bahwa UMK terendah terdapat di Kabupaten Banjarnegara sebesar Rp1.748.000, sedangkan UMK tertinggi di Kota Semarang sebesar Rp2.715.000, dan Kabupaten Banyumas sebesar Rp1.900.000 (BPS Provinsi Jawa Tengah, 2019).

\section{Pengeluaran Konsumsi Pengrajin Batik Wanita KUB Pringmas di Desa Papringan}

Pengeluaran konsumsi pengrajin batik wanita merupakan sejumlah uang yang harus dikeluarkan pengrajin batik wanita untuk membantu memenuhi kebutuhan hidupnya. Pengeluaran konsumsi pengrajin batik wanita meliputi dua indikator yaitu konsumsi makanan dan non-makanan. Berikut hasil analisis pengeluaran konsumsi pengrajin batik wanita KUB Pringmas dijelaskan sebagai berikut: 
Recha Pangestika, Herman Sambodo, Goro Binardjo dan Sodik Dwi purnomo, Pendapatan, Konsumsi dan Tingkat Kesejahteraan Pengrajin Batik Wanita KUB Pringmas di Desa Papringan Banyumas

Tabel 5. Perbandingan Antara Total Pengeluaran dan Rata-Rata Pengeluaran Konsumsi Pengrajin Batik Wanita (dalam Rp)

\begin{tabular}{cccc}
\hline Jenis Pengeluaran Konsumsi & \multicolumn{2}{c}{ Total Pengeluaran Rata-rata } & $\begin{array}{c}\text { Pengeluaran Konsumsi } \\
\text { (Persentase) }\end{array}$ \\
\hline Makanan & Konsumsi & Pengeluaran Konsumsi & 80,28 \\
Non-Makanan & $21.470 .000,00$ & $565.000,00$ & 19,72 \\
\hline
\end{tabular}

Sumber: Data Primer Diolah, 2020

Berdasarkan Tabel 5. di atas menjelaskan bahwa total pengeluaran konsumsi makanan lebih banyak dibandingkan dengan total pengeluaran konsumsi nonmakanan yaitu rata-rata pengeluaran sebesar Rp 565.000 untuk pengeluaran makanan dan sebesar Rp 138.815,79 untuk pengeluaran non-makanan, sehingga terdapat perbedaan Rp 426.184,21 antara pengeluaran makanan dan non - makanan. Pengeluaran konsumsi makanan mendominasi yaitu sebesar $80,28 \%$ dan sisanya sebesar $19,72 \%$ digunakan untuk pengeluaran konsumsi nonmakanan. Pengeluaran konsumsi makanan yang terdiri dari bahan makanan pokok seperti sayuran, buahbuahan, sumber protein hewani (daging,ikan,telur), minyak, beras, dan lain-lain. Sedangkan pengeluaran non- makanan terdiri dari sandang seperti pakaian, sepatu/sandal, alat mandi, listrik, air, gas, biaya pendidikan dan lain-lain.

Model persamaan regresi linier sederhana dirumuskan sebagai berikut:

$\mathrm{C}=\mathrm{a}+\mathrm{bY}$

$\mathrm{C}=61.713,48+0,77 \mathrm{Y}$

Model persamaan regresi linear sederhana di muka, menjelaskan koefisien konstanta sebesar
$61.713,48$ yang berarti konsumsi minimal yang harus dikeluarkan sebesar $\mathrm{Rp} 61.713,48$ apabila tidak berpendapatan atau pendapatan sebesar $\mathrm{Rp} 0$. Nilai b/koefisien regresi/MPC sebesar 0,77 berarti menjelaskan apabila pendapatan meningkat sebesar $\mathrm{Rp}$ 100.000 maka konsumsi akan meningkat sebesar Rp 77.000. Nilai b/koefisien regresi/MPC sebesar 0,77 atau $77 \%$ tambahan pendapatan digunakan untuk menambah besarnya konsumsi dan sisanya sebesar 0,23 atau $23 \%$ digunakan untuk menambah besarnya tabungan. Artinya, pendapatan pengrajin batik wanita KUB Pringmas masih sangat rendah.

Hasil analisis regresi menjelaskan bahwa t-hitung $15,018>$ t-tabel sebesar 2,028, sehingga kesimpulannya variabel pendapatan $(\mathrm{X})$ berpengaruh positif signifikan terhadap variabel konsumsi (Y).

Tabel 43. di atas menjelaskan bahwa variasi besarnya nilai korelasi atau hubungan (R) yaitu sebesar 0,929. Berdasarkan hasil output tersebut diperoleh koefisien determinasi ( $\mathrm{R}$ Square) sebesar 0,862, yang menjelaskan bahwa 86,2 \% variasi besarnya nilai konsumsi dijelaskan oleh variasi variabel konsumsi dan sedangkan sisanya dijelaskan oleh variabel lain di luar penelitian ini yaitu sebesar $13,8 \%$.

Tabel 6. Hasil Estimasi Regresi Linier Sederhana

\begin{tabular}{|c|c|c|c|c|}
\hline Variabel & Koefisien & $\mathrm{T}$ hitung & Sig. & \\
\hline $\mathrm{C}$ & $61.713,476$ & 1,162 & 0,253 & \\
\hline Pendapatan & 0,774 & 15,018 & 0,000 & \\
\hline $\mathrm{R}$ & & & & 0,929 \\
\hline R Square & & & & 0,862 \\
\hline F hitung & & & & 225,532 \\
\hline F tabel & & & & 2,028 \\
\hline Sig. & & & & 0,000 \\
\hline T tabel & & & & 2,028 \\
\hline
\end{tabular}

Sumber: Data Primer SPSS 25, 2020

Kesejahteraan Pengrajin Batik Wanita KUB Pringmas di Desa Papringan

Menurut Puspitasari et al. (2013) menjelaskan bahwa kontribusi wanita berdasarkan pada banyaknya orang yang bekerja dalam satu rumah. Kesejahteraan pengrajin batik wanaita KUB Pringmas diukur dengan menggunkan Standar Kebutuhan Hidup Layak yang mengacu pada Upah Minimum Kabupaten (UMK).

Tabel 7. Data Tingkat Kesejahteraan Pengrajin Batik Wanita KUB Pringmas Berdasarkan Upah Minimum Kabupaten (UMK)

\begin{tabular}{lrr}
\hline Tingkat Kesejahteraan & Frekuensi & Persentase $(\%)$ \\
\hline Tidak Sejahtera & 36 & 94,74 \\
Sejahtera & 2 & 5,26 \\
\hline Total & 38 & 100,00 \\
\hline
\end{tabular}

Sumber: Data Primer Diolah, 2020 
Tabel 7 menunjukkan bahwa tingkat kesejahteraan pengrajin batik wanita KUB Pringmas berdasarkan UMK atau Upah Minimum Kabupaten Banyumas yaitu Rp 1. 900.000. Berdasarkan data penelitian menyatakan bahwa sekitar $94,74 \%$ atau sebanyak 36 orang responden atau dari seluruh pengrajin batik wanita KUB Pringmas memiliki pendapatan dibawah UMK atau Upah Minimum Kabupaten Banyumas yaitu sebesar Rp 1.
900.000, sehingga dapat dikategorikan tidak sejahtera. Sedangkan sisanya sebanyak 2 orang responden atau sekitar 5,26\% memiliki pendapatan di atas Upah Minimum Kabupaten (UMK) Banyumas, sehingga dikategorikan sejahtera. Kesejahteraan rumah tangga pengrajin batik wanita KUB Pringmas dapat dianalisis melalui indikator kesejahteraan menurut BKKBN, yaitu sebagai berikut:

Tabel 8. Tingkat Kesejahteraan Pengrajin Batik Wanita KUB Pringmas Berdasarkan Indikator Kesejahteraan Keluarga BKKBN

\begin{tabular}{clcc}
\hline No & \multicolumn{1}{c}{ Tingkat Kesejahteraan } & Jumlah Pengrajin Batik Wanita & Persentase $(\%)$ \\
\hline 1. & Pra Sejahtera & 0 & 0,00 \\
2. & KS I (Keluarga Sejahtera I) & 8 & 21,06 \\
3. & KS II (Keluarga Sejahtera II) & 9 & 23,68 \\
4. & KS III (Keluarga Sejahtera III) & 9 & 23,68 \\
5. & KS III Plus (Keluarga Sejahtera III Plus) & 12 & 31,58 \\
Jumlah & & 38 & 100,00
\end{tabular}

Sumber: Data Primer Diolah, 2020

Tabel 8 menujukkan bahwa tingkat kesejahteraan pengrajin batik wanita KUB Pringmas berdasarkan indikator kesejahteraan BKKBN. Tabel tersebut menunjukkan bahwa sudah tidak terdapat masyarakat yang berada dalam kondisi Pra Sejahtera. Sementara jumlah yang terbanyak terdapat pada kondisi KS III Plus (Keluarga Sejahtera III Plus) sebanyak 12 orang atau sekitar 31,58\%, selanjutnya KS III (Keluarga Sejahtera III) dan KS II (Keluarga Sejahtera II) secara bersama sebanyak 9 orang atau sekitar 23,68\% dan sisanya berada pada kondisi Keluarga Sejahtera I sebanyak 8 orang atau sekitar $21,06 \%$.

\section{SIMPULAN}

Berdasarkan hasil penelitian, mayoritas pengrajin batik wanita KUB Pringmas berkontribusi rendah terhadap pendapatan rumah tangganya. Hal tersebut dikarenakan pekerjaan pembatik saat ini masih belum menjadi pekerjaan utama, namun masih merupakan pekerjaan sampingan, di samping itu jam kerjanya pun masih di bawah jam kerja normal. Pendapatan pengrajin batik wanita KUB Pringmas berpengaruh positif dan signifikan terhadap pengeluaran konsumsinya. Dengan MPC 0,77 (di atas 0,5). Pengeluaran konsumsi pengrajin batik wanita KUB Pringmas sebagian besar digunakan untuk konsumsi makanan. Mayoritas pengrajin batik wanita tergolong tidak sejahtera karena sebagian besar memiliki pendapatan di bawah UMK yaitu sebesar Rp 1.900.000, sehingga belum dapat memenuhi standar kebutuhan hidup layak. Berbeda dengan tingkat kesejahteraan rumah tangga pengrajin batik wanita KUB Pringmas telah melewati kategori Pra Sejahtera dengan terpenuhinya kebutuhan dasar minimum. Rumah tangga pengrajin batik wanita mendominasi pada kategori tinggi yaitu Keluarga Sejahtera III Plus (KS III Plus).

Berdasarkan hasil penelitian, pembatik perlu dijadikan pilihan sebagai pekerjaan utama, disamping situ pengrajin batik wanita diharapkan bekerja sesuai dengan jam kerja normal. Hal lain yang tidak kalah penting perlu adanya pelatihan untuk meningkatkan keterampilan pembatik, mengingat pengrajin batik wanita termasuk pekerja kurang terlatih (non skilled worker). Memprioritaskan pengeluaran konsumsi untuk memenuhi kebutuhan primer berupa pemenuhan makanan dalam melangsungkan hidup, sisanya dapat dimanfaatkan untuk pengeluaran konsumsi nonmakanan. Perlunya pendampingan untuk mengefektifkan pelatihan pada KUB Pringmas melalui Usaha Peningkatan Pendapatan Keluarga Sejahtera (UPPKS) sebagai suatu model dalam pemberdayaan dan upaya peningkatan kesejahteraan pembatik wanita secara kolektif. Temuan ini sejalan dengan Sari, Haryono, \& Rosanti (2014) yang meneliti itmglat kesejahteraan rumah tangga petani jagung. Hasil penelitianya menunjukkan bahwa usaha tani jagung memiliki kontribusi terhadap pendapatan keluarga sebesar $86,01 \%$. Selain itu, tingkat kesejahteraan sebesar 70.59\% dikategorikan sejahtera. Temuan Yulhendri \& Susanti, (2017) juga menjelaskan bahwa variabel yang paling dominan terhadap kesejahteraan adalah kepemilikan kekayaan material.

\section{DAFTAR PUSTAKA}

Badan Pusat Statistik. (2019). Kecamatan Sokaraja dalam Angka 2019. BPS Kabupaten Banyumas. Banyumas.

Badan Pusat Statistik. (2019). Provinsi Jawa Tengah dalam Angka 2019. BPS Provinsi Jawa Tengah. Semarang.

Badan Pusat Statistik. (2018). Profil Ketenagakerjaan Kabupaten Banyumas Hasil SAKERNAS Agustus 2018. BPS Kabupaten Banyumas. Banyumas.

Dinas Tenaga Kerja, Koperasi \& UKM Kab. Banyumas Tahun 2018.

Gilarso. (2004). Pengantar Ilmu Ekonomi Makro.Yogyakarta: Kanisus 
Recha Pangestika, Herman Sambodo, Goro Binardjo dan Sodik Dwi purnomo, Pendapatan, Konsumsi dan Tingkat Kesejahteraan Pengrajin Batik Wanita KUB Pringmas di Desa Papringan Banyumas

Kementerian Perindustrian Republik Indonesia. (2019).

Diminati pasar global, ekspor batik dibidiknaik 8

persen. Jakarta: Penulis. Diakses dari https://www.kemenperin.go.id/artikel/20650/Dimi nati-Pasar-Global,-Ekspor-Batik-Dibidik-Naik-8Persen

Puspitasari, N., Puspitawati, H., \& Herawati, T. (2013). Peran Gender, Kontribusi Ekonomi Perempuan, Dan Kesejahteraan Keluarga Petani Hortikultura. Jurnal Ilmu Keluarga \& Konsumen, 6(1), 10-19. https://doi.org/10.24156/jikk.2013.6.1.10

Putra, S., Istiqomah, I., Gunawan, D., \& Purnomo, S. (2020). Analisis Pendapatan dan Nilai Tambah Industri Pengolahan Kopi : Pendekatan Metode Hayami. Efficient: Indonesian Journal of Development Economics, 3(3), 994-1005. https://doi.org/10.15294/efficient.v3i3.43518

Sari, K.D, Haryono, D., \& Rosanti, N. (2014). Analisis Pendapatan Dan Tingkat Kesejahteraan Rumah Tangga Petani Jagung Di Kecamatan Natar Kabupaten Lampung Selatan. Jurnal Agribisnis. 2(1), 64-70. http://dx.doi.org/10.23960/jiia.v2i1.64-70.

Sukirno, S. (2000). Makroekonomi Modern. Jakarta: PT Raja Grafindo Persada Kencana

Yulhendri, Y \& Susanti, N. (2017). Analisis Konfirmatory Faktor Pengukuran Indikator Kesejahteraan Rumah Tangga. Jurnal Ilmiah Econosains, $\quad 15(2), \quad 185-201$. $\underline{10.21009 / \text { econosains. } 0152.02}$ 